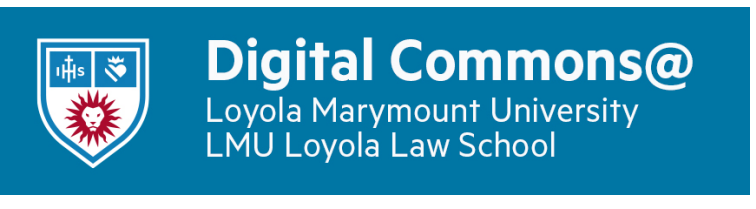

Journal of Catholic Education

\title{
The Character, Mission, and Future of Lutheran Higher Education
}

Mark R. Schwehn

Follow this and additional works at: https://digitalcommons.Imu.edu/ce

\section{Recommended Citation}

Schwehn, M. R. (2003). The Character, Mission, and Future of Lutheran Higher Education. Journal of Catholic Education, 6 (4). http://dx.doi.org/10.15365/joce.0604032013

This Focus Section Article is brought to you for free with open access by the School of Education at Digital Commons at Loyola Marymount University and Loyola Law School. It has been accepted for publication in Journal of Catholic Education by the journal's editorial board and has been published on the web by an authorized administrator of Digital Commons at Loyola Marymount University and Loyola Law School. For more information about Digital Commons, please contact digitalcommons@lmu.edu. To contact the editorial board of Journal of Catholic Education, please email JCE@nd.edu. 


\title{
THE CHARACTER, MISSION, AND FUTURE OF LUTHERAN HIGHER EDUCATION
}

\author{
MARK R. SCHWEHN \\ Christ College \\ Valparaiso University
}

This article looks at the history of Lutheran higher education in the United States, discusses what Lutheran institutions of higher education must do to remain vital centers of learning, and examines questions that face American higher education in general.

T utheran higher education in the United States has enjoyed a complex and Ldistinguished history over the past 150 years. But like most church-related colleges, Lutheran colleges and universities must now reform their thinking and practices if they are to remain vital centers of learning well into the present century. If Benne (2001) is correct, Lutherans can take heart from institutions of higher learning like Valparaiso University and St. Olaf College that have achieved and maintained "quality with soul" in a time of increasing secularization. But even these schools face enormous difficulties in their endeavors to articulate and implement a credibly Lutheran form of higher education that engages the loyalty and support of Lutheran churches and lay people, much less the larger American public. Lutherans tend to think dialectically, historically, and contextually. Their future success, measured by their own lights, will be determined in large part by how well they answer a series of fundamental questions now facing American higher education generally.

The scope and character of the multiple problems faced by Lutheran colleges and universities can best be sketched through a brief consideration of Burtchaell's (1998) enormous historical study of the fate of church-related colleges and universities in the United States, The Dying of the Light. Perhaps the most vexing problem faced by Lutheran colleges and universities is the apparent indifference to the Lutheran character of Lutheran institutions by many Lutherans themselves, resulting in enrollment crises or in radical and unplanned changes in the religious composition of the student bodies at 
Lutheran institutions. According to Burtchaell, this is really an old story for Lutherans and for most other Christians.

Most of the church-related colleges and universities Burtchaell analyzes began with fairly loose ties to their national church bodies (though there were strong regional ties for many of them), and they continued for long periods with only modest support from those churches. There was, with few exceptions such as the Lutheran Church, Missouri-Synod (LCMS) schools, no "golden age" of close and substantial relationships among churches, their colleges, and their constituents. Indeed, in almost all of the Lutheran cases, the concern for Lutheran character-the need first to specify and then to achieve a distinctively Lutheran form of higher education-was the result of often irreversible declines in the standard measurements of church-relatedness: the percentages of Lutheran students, faculty, and administrators; the number of required theology courses; the attendance at worship services; and so forth.

Much of Burtchaell's intermittent, more general analysis of the causes of the gradual disengagement of colleges and universities from their sponsoring church bodies applies, albeit unevenly, to Lutheran institutions. This analysis is not easy to summarize, partly because it is difficult to locate in the massive narrative of Dying of the Light. Sometimes Burtchaell seems to argue that the principal cause of estrangement was a structural one in that the ties that bound church to college or university were too weak from the outset to withstand the onslaughts of modernity. At other times, he seems to suggest that his book is but one chapter in the much larger story of the assimilation of ethnic and religious groups into the mainstream of American culture. Most of the time, however, Burtchaell presents several variations on a basic story of well-meaning but maladroit leaders who modified and diluted the churchrelated character of their schools for the sake of economic gain or academic quality as judged by secular standards.

All of these factors were surely involved for Lutherans, but Burtchaell's analysis of the estrangement of Lutheran colleges and universities from their churches highlights three additional factors: first, the tendency of Lutherans, especially but not exclusively the LCMS, to sponsor too many schools and to continue to maintain them long after this became impractical; second, the surprising absence of a robust, critical theology of education or Biblical hermeneutic in a church that had every reason to develop both of these things, especially at their colleges and universities; and finally, the pietistic vein of Lutheranism that relegated Christianity to the margins of academic life by making it strictly a matter of personal faith rather than a matter of common intellectual endeavor, a matter of the heart over the head, a matter of prayer and worship often to the exclusion of hard intellectual work, not only in theology but also in the shaping of the whole academic community (Burtchaell, 1998). There simply is not now, nor has there ever been, a 


\section{Lutheran equivalent to Cardinal Newman.}

Burtchaell (1998) readily acknowledges that these social and theological problems do not pertain equally to all Lutheran colleges and universities at all times; thus, he might welcome Benne's aforementioned corrective to his own argument in Quality with Soul. And all statements about Lutheran colleges and universities must be qualified by the recognition of the immense differences among the colleges and universities that call themselves Lutheran, especially the differences between the schools of the LCMS and those of the Evangelical Lutheran Church of America (ELCA). Even so, almost all of these colleges and universities have become increasingly secularized as the ethnic groups that founded them (largely German and Scandinavian) have become more assimilated into the mainstream of American life. All of them have found it increasingly difficult to recruit excellent Lutheran faculty who have maintained their theological commitments in the face of the overwhelming secularity of the great research universities where most of them are trained. And all of them are informed more or less by certain theological understandings that are on the one hand the sources of their greatest strengths and potentials and on the other hand the sources of their greatest weaknesses and perils.

Foremost among these informing theological ideas are several notions: that Christ and culture, faith and reason, are finally in tension with one another; that all Christians are called by God to the work that they do in the world; and that Lutheranism is most basically a confessional movement within the Catholic church that strives always toward unity among all Christians. The persistence of Lutheran identity within the field of American higher education during the 21 st century will depend in large part upon the extent to which these ideas are developed and applied in fresh and persuasive ways. And their proper application will take place in an effort to address fundamental questions set before Lutheran institutions by the larger culture of which they are a part and which they seek to serve and challenge and improve. What then are those questions, and how might Lutheran colleges and universities begin to address them in a way that is both faithful to their tradition and visibly serviceable to the modern world?

\section{QUESTIONS}

These questions are fundamental because, though they may be formulated somewhat differently than I will formulate them here, they will in fact undergird and inform the predictable surface discourse about information technology, shifting demographics, the impact of market forces upon university research, rising costs, and so forth. Surely there is a sense in which these material and technological forces will propel developments just as much as, if not more than, the force of ideas. But colleges and universities stand or fall 
by the strength of their ideas and their ideals. And the future of Lutheran higher education will be bright or dim depending in large part upon the efficacy and credibility of its answers, in words and in deeds, to these questions.

There are at least four such questions. First, to what extent, if any, can universities credibly remain integral and coherent communities of learning without transcendent horizons? Second, can higher learning in America retain its vitality if it loses the plurality of institutions that collectively advance it? Third, can the persistent decline of liberal learning relative to socalled vocational preparation be arrested without some kind of imaginative reconception of the whole relationship between liberal education and preparation for vocations? And finally, a question that in some ways encompasses all of the others: Can a liberal democracy continue to be served by higher education that exalts ideals of freedom, enlightenment, progressive development, problem solving, and the relief of humankind's estate without commensurate attention to the meaning and significance of the overwhelming facts of human mortality and finitude? Or, to put the matter more bluntly, can higher learning remain credible in the next century in the face of the facts of the past century if it continues as a kind of subtle denial of death?

The first question would seem the easiest to answer, but it is probably the most difficult, the most pertinent, and the most consequential of the four: To what extent, if any, can colleges and universities remain integral and coherent communities of learning without transcendent horizons? By transcendent horizons, I simply mean ends that point beyond contingent human purposes and goods. In other words, not what is good for humankind simply but what is truly good, period; not simply whatever is taken to serve a given historical constellation of human wants and needs, but what might point toward at least some truths that are eternal. Most devout religious believers will have a sense of transcendent horizons, but not all people who have such a sense will necessarily be religious. Most of those who do have a sense of transcendent horizons will think of the purposes of communities of learning primarily in terms of their collective pursuit of the truth of matters; most of those who lack such a sense will think of the purposes of such communities primarily in terms of the relief of humankind's estate. And of course, in practice, almost all college and university mission statements at both secular and church-related institutions split the difference by including some version or another of both sets of purposes.

At this point in human history it is simply not clear to what extent the internal coherence and integral character of universities depend upon a sense of the transcendent. When MacIntyre (1999) wonders whether the great research universities in this country are universities in anything but name, he is worried precisely about a loss of intellectual coherence and integrity. And when Hollinger (2000) worries over a lack of solidarity among university faculty, he connects that loss in part to the parceling out of faculty loyalty 
and attention to a variety of projects extraneous to the university, many of them indisputably linked to the project of human flourishing. But neither thinker argues that the achievement of coherence among the several intellectual enterprises within a university depends necessarily upon a sense of transcendent horizons. Though MacIntyre discusses at some length the integrative role of theology at Catholic universities, he states flatly that "the integrative task is a task for secular reason and a task for the secular university" (p. 2). And Hollinger would invoke something like the scientific ideals and the communal sense of truth in the philosophy of Charles Sanders Peirce to provide the integrative ethos of the modern university at its best.

There is nevertheless a profound difference between the motives and the basic beliefs that power a "blessed rage for order" and the actual terms of any such coherence once established. The latter architectonics are all indeed contingent and provisional achievements, including those, like the Thomistic synthesis, that some thinkers like MacIntyre have recommended in a varied form for the present day. Oakley (1992) is surely right to object to "educational fundamentalism," and to argue that it is "no longer possible to ground desired coherence in some sort of agreed-upon unitary curricular content determined in accord with universal norms and values of our inherited common culture" (p. 159). But the question of transcendent horizons is a question about what finally both inspires and beckons the quest for coherence, not about the terms of its negotiation. Oakley closes his elegant little book on liberal education with a quotation from Alfred North Whitehead that captures very well the educational faith of one speaking from a sense of transcendent horizons. Whitehead's words, Oakley writes,

relay harmonics of a larger hope, of that faith in reason, that trust (he says) "that the ultimate natures of things lie together in a harmony that excludes mere arbitrariness," that conviction that "detached details, merely in order to be themselves, demand that they should find themselves in a system of things," that stubborn sense, even, "that our experience, dim and fragmentary as it is, yet sounds the utmost depths of reality. (pp. 172-173)

Lutheran teaching and practice about this fundamental question should, if the project of Lutheran higher education is to endure through the next century, render the Lutheran sense of the integral connection between the transcendent and the internal coherence of their own communities of learning clear, explicit, and compelling. Lutherans, must, in short, develop a richer theological understanding of the nature and purposes of higher education than they have heretofore. Though there is not any Lutheran equivalent of Cardinal Newman looming on the horizon, there are some instructive sources of hope and encouragement in this regard. First of all, Lutherans have been forcibly instructed by their Calvinist colleagues to discover the importance 
of a systematic theology of education, like the one developed by the Dutch Reformed thinker Abraham Kuyper at the end of the 19th century, to the continued vitality of schools like Calvin College. Second, a few Lutheran theologians and ethicists, like Professors Ernest Simmons (1998) and Robert Benne (2001), have devoted increasing amounts of their scholarly energies to formulating a theology of higher education. Finally, some evangelicals, like Mark Noll (1992), and some leading experts in the field of Christian higher education, for example Professor Richard Hughes (2002) of Pepperdine, have recently observed that Lutherans have implicitly and potentially the best theology of higher education in our time, though neither one of these scholars believes that it has yet been articulated with appropriate force and vigor.

The impetus for Lutherans to attend theologically to higher education has been the strenuous efforts of a number of Lutheran college and university presidents to renew and strengthen the Lutheran character of their institutions. As a result, several schools like St. Olaf College, ConcordiaMoorhead, and Valparaiso have produced collections of essays for the purposes of initiating new faculty into their communities that contain the seeds of a more robust Lutheran theology of higher education. And under the direction of the higher education office of the Evangelical Lutheran Church in America, a Lutheran Academy of Scholars, based on the NEH summer seminar model, has been launched to promote the kind of thinking that may well lead to a more comprehensive Lutheran understanding of scholarship, teaching, learning, knowledge formation, and the university.

It is too early to predict what these several endeavors might yield, but they should gradually demonstrate how the Lutheran understanding of the transcendent can give particular shape and substance to the course of study offered at Lutheran colleges and universities. Luther's own favorite Gospel begins with a great hymn to the Logos-a word, an order, a pattern, a reason-that was present from eternity and that must in some way or another inform all human endeavors to pursue the truth, an enterprise that must include discovery as much as, if not more than, invention. As Lutherans develop a more adequate theology of higher education, they might well begin at this beginning, probing the implications for teaching, learning, and scholarship of the claim that "In the beginning was the Word." And though they have already created a remarkable number of regular occasions for collaborative work among faculty from several Lutheran academies, they will need to be even more visionary in the coming century. Fledgling centers for Lutheran scholarship and theological reflection must be consolidated and strengthened. 


\section{INSTITUTIONAL PLURALISM}

If the first of our four questions is the most difficult to answer, the second one may well be the easiest: Can higher learning in America retain its vitality if it loses the plurality of institutions that collectively advance it? It seems very doubtful that it can. From 1999-2001, I was a member of the National Lilly Seminar on Religion and Higher Education, a diverse and contentious group of scholars representing many academic disciplines and points of viewsome religious, others wholly secular. The group reached consensus on almost nothing pertaining to the broad subject of the relationship between Christianity and the academy other than the view that institutional pluralism is a good thing for higher education (Sterk, 2002). Institutional pluralism must be sharply distinguished from distributional pluralism, which concerns the ethnic and racial diversity on any given college or university campus. Though the two types of pluralism are sometimes in tension with one another, prudent leadership can harmonize these very different goods without succumbing to the extreme remedies sometimes suggested by exclusive attention to either one.

Lutheranism will face its greatest challenge over the course of the next century in its endeavors to contribute to the general good of institutional pluralism by strengthening the ties between its academies and its churches and by sharpening some of the more unique and salutary features of its own religious and cultural practices, such as the composition and performance of great church music. In order to flourish, Lutheran colleges and universities will have to do nothing less than to discover and to some extent form a college- and university-related church to support the church-related university. This church will not coincide with individual parishes or even with the national Lutheran church bodies which have never been especially generous with financial support for Lutheran colleges and universities. It will consist instead of Lutheran lay people who long for theological substance and spiritual wisdom that is commensurate with the advanced knowledge that informs other aspects of their lives; of Lutheran parents of prospective students who want to provide their children with an excellent education but who are almost completely unaware of the present quality of their own colleges; and of prosperous Lutherans who can be persuaded to support some of the pan-Lutheran endeavors that are necessary to transmit and enrich the best of the Lutheran tradition.

One substantial effort to form and inform such a college- and universityrelated church has demonstrated by its very success the magnitude of the task that remains. The Lutheran Educational Conference of North America (LECNA), made up of all the Lutheran college and university presidents, recently commissioned a massive sociological study of Lutheran graduates of Lutheran colleges and universities by comparison to Lutheran graduates of flagship state universities and Lutheran graduates of secular, private liberal 
arts colleges. The study showed that substantially higher percentages of Lutheran graduates of Lutheran schools serve as volunteers, assume positions of leadership in their churches, and participate regularly in civic activities than Lutheran graduates of flagship public institutions. Moreover, the Lutheran graduates of Lutheran colleges and universities were considerably more satisfied by both the quality and the relevance of their education than were the Lutheran graduates of flagship state institutions and secular, private liberal arts colleges.

Though this news was reassuring to the presidents who had commissioned it, other news generated by the same study demonstrated the daunting task before them. An overwhelming majority of the parents of prospective Lutheran students were completely ignorant of the strengths that their own Lutheran colleges and universities possess. Moreover, very few of them who were aware of the academic quality of these schools were attracted to them because of their distinctively Lutheran emphases or practices. Indeed, the most underestimated factor in books, such as Burtchaell's Dying of the Light, that seek to explain the estrangement between churches and their colleges and universities has been the deep desire of ethnic and religious groups to assimilate into the mainstream of American culture. Millions of German and Scandinavian Lutheran parents have spurned their own colleges and universities over the years in order to secure for their children, through enrollment in "more prestigious" secular schools, what they take to be full and lucrative participation in the promises of American life. As a result, last year only $4 \%$ of Lutheran high school graduates attended a Lutheran college or university.

If one adds to this problem the weakening of denominational ties and the breakdown in the larger ecology of Lutheran elementary schools, high schools, and parishes that at one time fed Lutheran colleges and universities with students, the future of Lutheran higher education would seem bleak indeed. And unless these colleges and universities do begin to serve the church, they will either become secularized themselves in an endeavor to reach a more general constituency or they will slowly fail. There are already some very successful programs underway, however, that can serve as models for creating a college- and university-related church. One such program, the renowned Lutheran Summer Music (LSM) camp, attracts hundreds of superb high school musicians, many of them Lutheran, and provides them with 4 weeks of outstanding musical training. LSM migrates from one Lutheran college campus to another from year to year, and it achieves multiple objectives, all of which are vital to the future of Lutheran higher learning. It helps to strengthen and maintain a major part of the Lutheran cultural inheritance. It introduces hundreds of parents to one of the greatest strengths of Lutheran higher education. And it serves the church by providing the next generation of lay people with an ear for the best of Lutheran church music and with an appetite for the best of Lutheran worship and theological reflection. 


\section{LIBERAL EDUCATION AND VOCATIONAL PREPARATION}

The third question that will increasingly confront all of higher education in the next century is one that Lutheranism is well positioned to address: Can the persistent decline of liberal learning relative to so-called vocationalism be arrested without some kind of imaginative reconception of the whole relationship between liberal education and vocational preparation? Recent defenses of liberal education, such as Nussbaum's (1997) Cultivating Humanity and Ryan's (1998) Liberal Anxieties and Liberal Education, have noted with some alarm the decline of liberal education relative to various forms of vocational education. Although, as Ryan notes, more students than ever before in this country are pursuing traditional arts and sciences degrees, this is a function of the huge rise in the total number of people enrolled in post-secondary education. Over the course of the last 30 years, however, BAs in arts and sciences as a percentage of all degrees fell by half, by contrast to business degrees, which had been 30 years ago only a third as numerous as arts and sciences degrees but are now equal to them. Trends like these are very likely to continue.

Lutheran educators are apt to view these developments with mingled sentiments. On the one hand, Lutherans have been historically among the strongest defenders of liberal education (Solberg, 1997). Along with other Christians, they have consistently articulated the purposes of higher education partly in terms of the cultivation of the intellect for its own sake. On the other hand, Lutherans have been suspicious of accounts of liberal education that are elitist in an invidious sense, as though such studies were either reserved for those who do not need to work to earn a living or were themselves avenues to lives of leisured privilege. Lutherans have always understood their colleges and universities as preparing young men and women for life and for work, and they have therefore been less inclined than some others to draw a sharp line between knowledge for its own sake and knowledge for the sake of something else.

This relative reluctance to distinguish sharply between liberal education and vocational preparation has stemmed in part from the Lutheran understanding of "vocation" or "calling." According to Lutheran teachings, God calls each and every Christian first to himself in baptism and second to particular tasks for the sake of serving neighbors in need. No one of these callings is intrinsically more worthy than any other one. Almost every college and university in the United States emphasizes service in its mission statement. But for Lutheran Christians, the character of the service rendered through the vocation is distinctive both in terms of its motive-the call to love and serve the neighbor because we were first loved by God-and in terms of its manner, self-giving love according to the pattern set forth in the 
life and ministry of Jesus of Nazareth. For Lutherans, the quality of the work or the service rendered by the Christian will not necessarily differ from the quality of the same work or service rendered by the non-Christian. But its meaning will.

Because it is so deeply embedded within an entire way of life, the Lutheran concept of vocation will not be easily exportable to more general conversations about higher learning in the United States. Within Lutheran colleges and universities a deeper understanding of the concept of vocation might well lead to a complete reformulation of such fundamental educational matters as the nature of human excellence and the relationship between the active and the contemplative life. Outside of Lutheran colleges and universities, the concept of vocation might well act as a spur to a reappraisal of the kind of knowledge that liberal learning at its best can provide. The knowledge that integrates, that enables the knower to see life whole and that enlarges the mind, is the same knowledge that is part of the cultivation of good judgment and practical wisdom and that leads directly to the resourcefulness that makes for good leaders in the worlds of politics and commerce as much as the world of the academy. Indeed, much of the knowledge most worth having becomes a true possession, truly incorporated into the knower, if and only if it is put to use in the service of others.

Colleges and universities are, in other words, redefining the nature, the point, and the purposes of human knowledge, or they are having such redefinitions thrust upon them. External circumstances that have led to this situation include especially the increasing number of corporate, political, and other interest groups who sponsor a good deal of university research and who therefore dictate to some extent its character and the terms of its publication. But there are developments internal to colleges and universities as well that are making traditional distinctions between liberal and vocational education increasingly irrelevant to the actual shape and substance of higher learning. Examples include the rise of "service learning" programs, the blurring of disciplinary boundaries, the incorporation of moral and ethical instruction into the curricula of professional schools, various drastic reinterpretations of the meaning and purposes of the humanities, a body of feminist scholarship on multiple "ways of knowing," and an increasing emphasis throughout the curriculum upon collaborative research and understanding. The Lutheran understanding of vocation that connects the meaning of human work to both the character of the worker and the infinite horizon of the call to serve should be one resource for a more general public project of discovering ways to reconfigure the educational activities heretofore organized under the contrasting rubrics of liberal and vocational studies. 


\section{HUMAN MORTALITY AND FINITUDE}

The fourth question before us will prove the most disquieting for higher learning generally and the most decisive for Lutheran higher education. For if Lutheran colleges and universities cannot contribute to the exploration of this question, they will have little or nothing of distinctive or permanent value to contribute to the exploration of any question. Can a liberal democracy continue to be served by higher education that exalts ideals of freedom, enlightenment, progressive development, problem solving, and the relief of humankind's estate without commensurate attention to the meaning and significance of the overwhelming facts of human mortality and finitude? It may well be that the vocation of Lutheranism in our time with regard to this question will simply be to raise it, because almost everything in contemporary intellectual life and in American culture generally conspires to evade it. Yet simply on the basis of an elementary commitment to examine critically the most pressing and perplexing features of the worlds of nature and culture, all colleges and universities would seem obliged to consider what is arguably the most overwhelming fact of the preceding century: death in forms and places and orders of magnitude hitherto unimaginable. And if colleges and universities really do intend, as they invariably claim, to prepare young men and women for life as human beings and as citizens, not simply as bankers or lawyers or teachers, how can they do this credibly without seeking to enable students to consider death and what it signifies about the whole human condition? We are back once more to the first question, the question of horizons.

Lutheran colleges and universities will, if they are to continue to flourish, address questions of human mortality and finitude in an all-pervasive and characteristically Lutheran way. To be sure, the courses of study offered by Lutheran academies will include their share of courses about death and dying and their share of readings that explore the meaning of human life, but these will be for the most part similar to courses offered everywhere. More important will be the ways in which these communities corporately face the loss of loved ones in their midst and the loss of the friends and relatives of individual students and faculty. My own university is seldom more fully itself than when it gathers in the chapel for funerals and memorial services to mourn the deaths of faculty, students, and staff members. At these moments of worship the university is most authentically Lutheran and most fully inclusive. And there is a sense in which every one of the hundreds of worship services held every year are reminders of mortality. Worship and praise are in one respect gratefully exultant acknowledgements of our finite existence.

At the heart of Lutheranism is the theology of the cross, and on a Lutheran college or university campus that theology should have special and constitutive implications. The same divine Logos that was and is present from eternity and that supplies the pattern or ratio that warrants and empowers the 
free and relentless pursuit of the truth entered history in the form of a servant whose destiny was death on the cross and whose life was the pattern of selfgiving love. What the world regarded and still regards as the sign of ultimate defeat, God saw as victory. Thus, according to the Lutheran Christian, God meets us at the point of our deepest need and weakness, not at the point of our highest worldly achievement. We are saved, Martin Luther insisted, by grace through faith alone. All of our works, even works of the mind, come to naught by themselves.

All of this means that at Lutheran colleges and universities knowledge is linked finally to love rather than to power, and reason is given its fullest expression precisely because it is shown every day in one way or another to be powerless to save. Inquiry at Lutheran colleges and universities can therefore be unfettered and joyful precisely because the stakes of reason are not ultimate. At their best, Lutheran colleges and universities convey these sometimes-paradoxical truths in countless ways at all times. They number the academic days on a liturgical calendar. They remind students again and again that severity of academic judgment on their papers is always tempered by mercy on their souls. And they take pride in the collective achievement of academic excellence even as they give thanks to God for it as a divine blessing.

In sum, Lutheran colleges and universities strive to achieve a perfect synthesis between faith and reason and then distrust all such final solutions of fallen human intelligence. So they live uneasily. They honor and give thanks to God for the ordered activities of the human mind, yet they doubt whether any such activities can reach perfect truth. Freed by the Christian gospel to pursue the truth, they nonetheless profess that it is the truth that finally frees. The only truth that finally matters is gift, not something we achieve. As colleges and universities, they have at the center of their missions the transmission and creation of knowledge. As Lutheran colleges and universities, they at the same time insist that knowledge cannot finally save us. Thus, the acknowledgement of human finitude at Lutheran academies is bound up with the cruciform shape of the infinite horizon that finally give shape to them and with the practices that regularly remind students and faculty of the limits of reason.

\section{THE FUTURE OF LUTHERAN HIGHER EDUCATION}

The future of Lutheran higher education will depend finally on its capacity to maintain a lovingly critical perspective, in both theory and practice, upon educational projects that place an exclusively high premium upon knowledge as power. Much of that critique will be shared with other Christians. And though concepts like Christian vocation and the theology of the cross are 
deeply embedded within a particular way of life, some of the pedagogical and curricular practices that flow from them converge with similar practices that derive from other forms of educational life.

If I may close with a prediction, I do not think that the next century of higher education will be marked significantly by destructive arguments between Christians and non-Christians or between devoutly religious people and militantly secular people. Instead, I think, as I stated at the beginning of these reflections, that the real threats to higher learning come from vast changes in the way that knowledge is understood, transmitted, produced, and sold. I rather suspect that many devout Christians and many resolute secularists of my generation will seek from different motives to preserve the best of university life and culture against some of the more menacing onslaughts of global capitalism. All of us will insist, for example, on the public character of all research, and we will resist for as long as we can the notion that the research we and our colleagues do at the university should be sold privately to the highest bidder and kept secret, if only for a time, from the larger world of scholarship. We may even have occasion to revisit the ancient monastic prohibition against selling knowledge for money. This may lead us to agree also that even the modern secular academy that many of us have loved was bound more deeply than any of us had realized to asceticism. Finally, we will eventually come to agree as well that colleges and universities must remain committed to certain ideals of coherence, universality, and truth in order credibly to remain universities.

The process of discovering agreement about these matters among the very diverse friends of the university is well underway. In a recent essay on academic freedom, the eminent Palestinian critic of Western imperialism Edward Said develops at considerable length the image of the traveler or migrant as the ideal of academic citizenship. For Said, academic freedom entails liberation from, among other things, the narrower identities that enslave us:

To assume that the ends of education are best advanced by focusing principally on our own separateness, our own ethnic identity, culture, and traditions, ironically places us where as subaltern, inferior, or lesser races we had been placed by nineteenth-century racial theory, unable to share in the general riches of human culture.... A single overmastering identity at the core of the academic enterprise, whether that identity be Western, African, or Asian, is a confinement, a deprivation. The world we live in is made up of numerous identities interacting, sometimes harmoniously, sometimes antithetically. Not to deal with that whole-which is in fact a contemporary version of the whole referred to by Newman as a true enlargement of mind-is not to have academic freedom. We cannot make our claim as seekers after justice that we advocate knowledge only of and about ourselves. Our model for academic freedom should therefore be the migrant or the traveler: for if, 
in the real world outside the academy we must needs be ourselves and only ourselves, inside the academy, we should be able to travel... among other selves, other identities, other varieties of the human adventure. But, most essentially, in this joint discovery of self and other, it is the role of the academy to transform what might be conflict, or contest, or assertion into reconciliation, mutuality, recognition, and creative interaction. (1996, pp. 226227)

The wisdom in this passage from Said should remind us once more that the endeavor to deepen Lutheran particularity will be in vain unless it points beyond itself to reconciliation with others. The passage also demonstrates the work of convergence, for Said develops his notion of academic freedom and intellectual integrity in the course of an elaborate dialogue with Cardinal Newman's (1902) The Idea of the University, the same work that inspired most of MacIntyre's lecture that I cited near the beginning of this essay. The Said essay was in turn one of the principal sources of support for Hollinger's aforementioned critique of the university and now for my own claim that the diverse friends of the university will increasingly find one another out, joining hands and hearts across differences of race, culture, and religion, to defend what is true and truly noble about academic life. The future of Lutheran colleges and universities will be inextricably linked to their own capacities to serve as charitable and astute allies in the continuing struggle to secure a bright future for all of higher education.

\section{REFERENCES}

Benne, R. (2001). Quality with soul: How six premier colleges and universities keep faith with their religious traditions. Grand Rapids, MI: Eerdmans.

Burtchaell, J. T. (1998). The dying of the light: The disengagement of colleges and universities from their Christian churches. Grand Rapids, MI: Eerdmans.

Hollinger, D. A. (2000). Money and academic freedom a half-century after McCarthyism: Universities amid the force fields of capital. In P. G. Hollingsworth (Ed.), Unfettered expression (pp. 161-184). Ann Arbor, MI: University of Michigan Press.

Hughes, R. (2002). How Christian faith can sustain the life of the mind. Grand Rapids, MI: Eerdmans.

MacIntyre, A. (1999, October). Catholic universities: Dangers, hopes, choices. Paper presented at a conference on Higher Learning and Catholic Traditions at the University of Notre Dame, Notre Dame, IN.

Newman, J. H. (1902). The idea of the university defined and illustrated. London: Bombay, Longmans, Green and Co.

Noll, M. (1992, February). The Lutheran difference. First Things, 36-37.

Nussbaum, M. (1997). Cultivating humanity: A classical defense of reform in liberal education. Cambridge, MA: Harvard University Press.

Oakley, F. (1992). Community of learning. New York: Oxford University Press.

Ryan, A. (1998). Liberal anxieties and liberal education. New York: Hill and Wang.

Said, E. (1996). Identity, authority and freedom: The potentate and the traveler. In L. Menand (Ed.), The future of academic freedom (pp. 214-228). Chicago: University of Chicago Press. 
Simmons, E. (1998). Lutheran higher education: An introduction for faculty. Minneapolis, MN: Augsburg Fortress.

Solberg, R. W. (1997). What can the Lutheran tradition contribute to Christian higher education? In R. T. Hughes \& W. B. Adrian (Eds.), Models for Christian higher education (pp. 71-81). Grand Rapids, MI: Eerdmans.

Sterk, A. (Ed.). (2002). Religion, scholarship, and higher education: Perspectives, models, and future prospects. Notre Dame, IN: University of Notre Dame Press.

An earlier version of this essay appeared as "Lutheran Higher Education in the Twenty-first Century," in P. Dovre (Ed.), The Future of Religious Colleges (Eerdmans, 2002).

Mark R. Schwehn is professor of humanities and dean of Christ College, the honors college of Valparaiso University. Correspondence concerning this article should be addressed to Dr. Mark R. Schwehn, Dean, Christ College, Valparaiso University, Valparaiso, IN 46383-6493. 
Copyright of Catholic Education: A Journal of Inquiry \& Practice is the property of Catholic Education: A Journal of Inquiry \& Practice and its content may not be copied or emailed to multiple sites or posted to a listserv without the copyright holder's express written permission. However, user's may print, download, or email articles for individual use. 